UTILIZING DOMAIN-SPECIFIC INFORMATION FOR PROCESSING COMPACT TEXT

\title{
Elaine Mersh
}

\author{
Lingulstic String Project \\ New York University
}

New York, New York

\section{ABSTRACT}

This paper Identlifles the types of sentence fragments found in the text of two damelns: medical records and Nevy equlpment status messages. The fragment types are related to full sentence forms on the basls of the elements which were regularly deleted. A breakdown of the fragment types and their distributions in the two domains is presented. An approach to reconstructing the semantic class of deleted elements in the medical records is proposed whlch is based on the semantic patterns recognized in the domaln.

\section{INTRODUCTION}

A large amount of natural language input, whether to text processing or questlon-answerling systems, consists of shortened sentence forms, sentence "fragments". Sentence fragments are found in informal technical communications, messages, headlines, and in telegraphle communications. Occurrences are characterlzed by their brevity and Informational nature. In all of these, if people are not restricted to using complete, gramatical sentences, as they are in formal writing situatlons, they tend to leave out the parts of the sentence which they bellove the reader will be able to reconstruct. Thls is especlally true if the writer deals with a speclalized subject matter where the facts are to be used by others in the $\operatorname{san} \theta$ tield.

Several approaches to such "lll-formed" natural language input have been followed. The LIFER system [Hendrix, 1977; Hendrix, et al.. 1978] and the PLANES system [Wal tz, 1978] both account for tragments in procedural terms; they do not require the user to enumerate the types of fragments wich wlll be accepted. The Linguistlc String Project has characterized the regularly occurring ungrammatical constructlons and made them part of the porsing grammar [Anderson, et al.. 1975; Hirschman and Sager, 1982]. Kwasny and Sondhe!mer (1991) have used orror-handling procedures to relate the 111 -formed input of sentence iragments to well-formed structures. Whlle these approaches differ in the way they determine the structure of the fragments and the deleted materlal, for the most part they rely heavlly, at some point, on the recognition of semantle word-classes. The purpose of this paper is to describe the syntactle characteristics of sentence tragments and to lllustrate how the domain-specific information embodied in the cooccurrence patterns of the semantlc word-classes of a domaln can be utllized as a powerful tool for processing a body of compact text, 1.e. text that contalns a large percentage of sentence fragments.

\section{IOENTIFICATION OF FRAGMENT TYPES}

The New York University Linguistic String Project has developed a computer program to analyze compact text In speclallzed subject areas using a general parsing progrom and an English grammar augmented by procedures specifle to the subject areas. In recent years the system has been tallored for computer analysis of free-text medical records, whlch are characterlzed by numerous sentence fragments. In the computer-enalysis and processing of the medical records, relatively few types of sentence fragments sufflced to describe the shortened forms, al though such fragments comprised fully 498 of the natural language input [Marsh and Sager, 1982]. Fragment types can be related to full forms on the basls of the el ements which are regularly deleted. El ements deleted from the frogments are from one or more of the syntactic positions: subject, tense, verb, object. The slx fragment types identifled in the set of medical records are shown In Table 1 as types $1-V I$.

A feoture of tragment types that is not Immediately obvious is the fact that they are already known in the full grammar as parts of fuller constructions. The fragment types reflect deletions found in syntactically distinguished positions within full sentences, as lllustrated in Table 2. For example, in normal English, a sentence that contalns tense and the verb be can occur as the object of verbs I Ike find (e.g. She found that the sentence us emblauous.). In the same environment, as object of find. a reduced sentence can occur in whlch the tense and verb be have been omitted, as in fragment type i le.g. She found the sentence amb(guous.). In the same manner, other reduced forms reflected in fragment types also represent constructions generally found as parts of regular English sentences.

The fact that the fragment types can be related to full English forms makes it possible to vlew them as instances of reduced SUBJECT-VEPB-OBJECT patterns from which particular components have been deleted. Fragments of type 1 can be represented as having a deleted tense and verb be, of type 11 as having a deleted subject, tense, and verb be, etc. This makes it relatively stralghtforward to add them to the parsing grammar. 

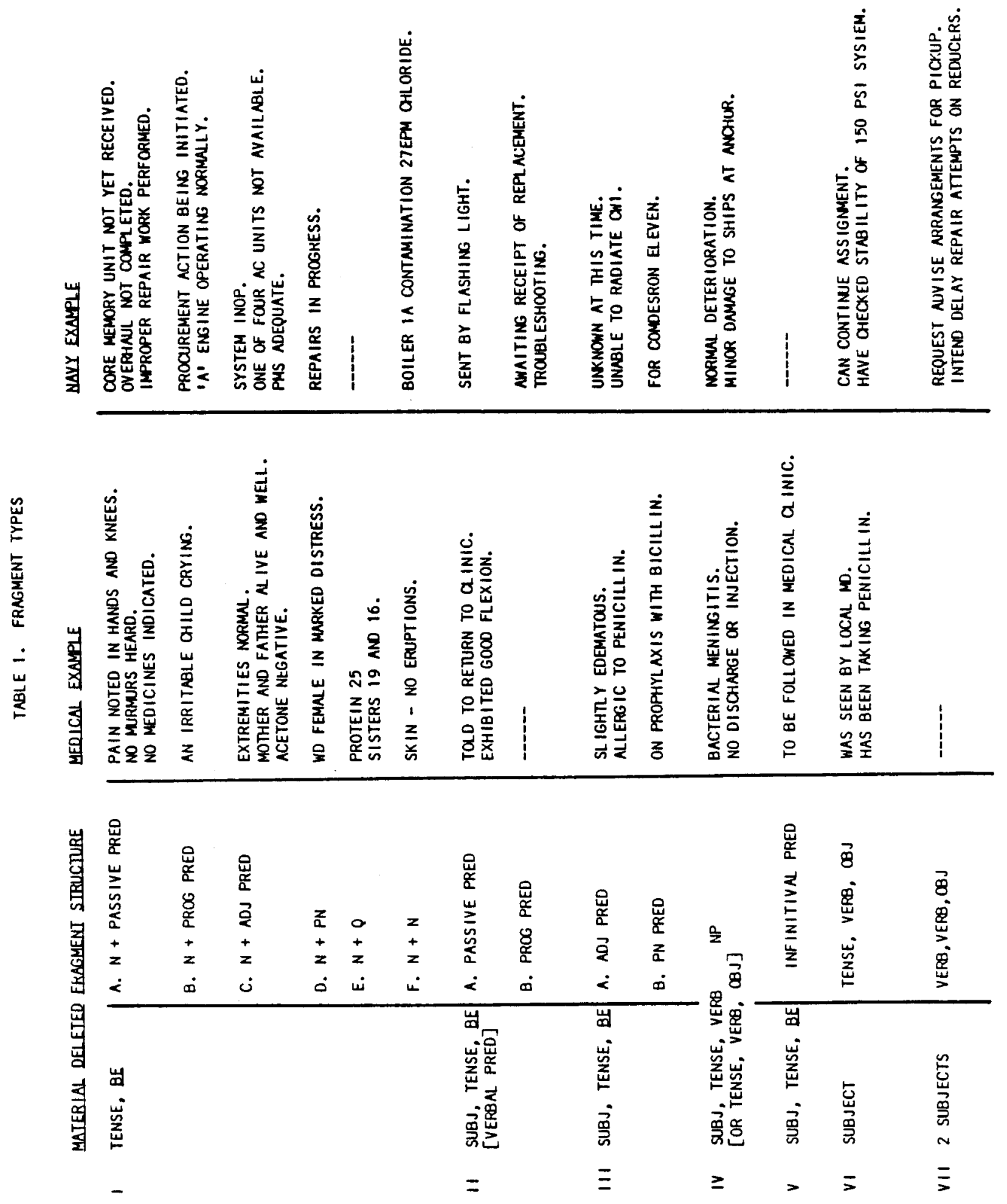
TABLE 2. DELETION FORMS IN NORMAL ENGLISH

1. DELETED TENSE, VERB BE
A. N + PASSIVE PRED
B. $N+$ PROGRESSIVE PRED
C. $N+$ ADJECTIVE PRED
D. $N+P N$
E. $N+Q$
F. $N+N$

THE KING HAD HIM BEHEADED. WE CBSERVED QULL IALKING IO HIMSEF. SHE FOUND THE SENTENCE ANBLGUOUS. THEY FOUNO HIS IDEA OE INTERESI. JOHN THOUGHT HIS 25 OB YOUNGER. THEY CONSIDERED HEB IHEIB SAYLIOUB.

11. DEEETED SUBJECT, TENSE, VERB BE [VEREN PREDICATE]
A. PASSIVE PREDICATE
THE MAN, EINLSHER WITH HLS WORS, WENT HOME. B. PROGRESSIVE PREDICATE MARY LEFT WHISTING $\triangle$ HAPPY IUNE.

111. DEETED SUBJECT, TENSE, VERB BE
A. ADJECTIVE PREDICATE
GRACLOUS AS EYEB, SHE WELCOMED HER GUESTS.
B. PN PREDICATE
THE GUARD, IN GREAI ALARY, CALLED THE POLICE.

iv. deleted subject, tense, Verb BE

NOUN PHRASE

THE CHILD, $\triangle$ CLUMSY DANCER, TWISTED HER ANKLE.

V. DELETED SUBJECT, TENSE, VERB BE

INFINITIVAL PREDICATE

THEY TOOK THE TRAIN IO AVOID THE IRAFFIC.

and, at the same time, provldes a framework for identifyling their semantic content by relating them to the corresponding full forms.

The number of fragment types that occur In compact text of different technlcal domalns appears to be relatively 1 imited. When the fragment types found in medical records were compared with those seen In a small sample of Navy equlpment status messages, five of the slx types found in the medical records were also found in the Navy messages. Only one addltlonel fragment type was required to cover the Navy messages. This type appears in Table 1 as type Vil, in which two subjects have been deleted (Bequest advlse arrangenents for plek up).

Whlle the number of fragment types is relatively constant, the distribution of fragment types varies according to the domain of the text. Table 3 shows distrlbutions for each of the fragment types identifled in Table 1. For example, in Table 3, while fragment type IV, from which subject, tense, and verb have been deleted, is most frequent in medical records, it is a much less frequent typo in the Navy messages. On the other hand, type $v i$, from whlch a subject has been deleted, is relatively infrequent in medical records, but much more frequent In Navy messages.

In addition, the different sections of the input differ with respect to the ratlo of fragments to whole sentences and in the types of frogments they contaln. For example, the different sections of the medical records that were analyzed (e.g. HISTORY, EXAM, LAB-DATA, IMPRESSION, COURSE IN HOSPITAL) were distInguished by differences in the distribution of the fragment types. The EXAM paragraph of the medical texts, in which the physiclan describes the results of the patient's -physlcal examination, contalned a relatively large number of fragments of type lll, especially adjective phrases. The COURSE IN HOSPITAL paragraph contalned a larger number of complete sentences than the other paragraphs.

\begin{tabular}{|ccc|}
\hline TABLE 3. & DISTRIBUTION OF FRAGMENT TYPES \\
IYPE & MEDICAL & NAYY \\
1. & 228 & $36 \%$ \\
11. & 18 & 68 \\
111. & 128 & 118 \\
IV. & 618 & 158 \\
V. & 18 & 08 \\
V1. & 28 & $28 \%$ \\
VI1. & 08 & 48 \\
\hline
\end{tabular}




\section{RECONSTRUCTION OF DELETIONS}

The deletions which relate tragment types to their full sentence forms fall into two main classes: (1) those found virtually in all texts and (ii) those speciflic to the domain of the text.

Just as the fragment types can be viewed as incomplete reallzations of syntactic $s-V-0$ structures, the semantlc patterns in sentence fragments can be considered Incomplete real izations of the semantlic S- -0 patterns. In general terms, the structure of information in technical domelns can be speclfied by a set of sementlc classes, the words and phrases which belong to these classes, and by a specification of the patterns these classes enter into, 1.e. the syntactic relationships among the members of the classes [Grishmen, et al.. 1982; Sager, 1978]. In the case of the medical sublanguage processed by the Linguistic String Project, the medical subclasses were derived through techniques of distrlbutlonal analysis [Hirschmen and Sager, 1982]. Semantle $S-V-0$ patterns were then derived from the comblnatory propertles of the medical classes in the text [Marsh and Sager, 1982]; the sementlc patterns identified in a text are speciflc to the domaln of the text. Whlle they serve to formulate sublanguage constraints which rule out incorrect syntactic analyses caused by structural or lexical ambigulty, these relationshlps among elasses can also provide a means by which deleted elements in compact text can be reconstructed. When a fragment is recognized as an Instance of a given sementic pattern, it is then possible to specify a set of the semantlc classes from whlch the medical sublanguage class of the deleted element can be selectod.

On a superficlal level, the deletions of be in fragment types $l c-f$ and $|1| a-b$, for example, can be reconstructed on purely syntactle grounds by fllling in the lexical ltem be. However, it is also possible to provide further information and speclfy the semantic class of the lexical item be by reference to the semantic $S-V-0$ pattern manlfested by the occurring subject and object. For example, in type if fragment skin no eruations, skin has the medical subclass BODYPART, and eruntions has the medlcal subclass SIGN/SYMPTOM.
The semantic S- $V-0$ pattern in whlch these classes play a part is: BOOYPART-SHOWV ERB-SIGN/ SYMPTOM

(as in Sklo showed no eruatlons). Be can then be assigned the semantlc class SHOWVERB. Proteic 25 , type le, enters into the semantic pattern: TEST-TESTVERB-TESTRESULT

and be can be assigned the class TESTVERB, which relates a TEST subject with a TESTRESULT object. Assigning a semantic class to the reconstructed be maximizes its informational content.

In addition to reconstructing a distinguished lexical Item, Ilke the verb be, along with its semantle classes. It is also possible to specify the set of semantic classes for a deleted el ement, even though a lexical item is not immediately reconstructable. For example, the fragment Io recelye felle acle, of Type VI, contains a verb of the PTVERB class and a MEDICATION Object, but the subject has been deleted. The only semantic pattern which permits a verb and object with these medical subclasses is the S-V-O pattern: PATIENT-PTV ERB-MED ICATION

Through recognition of the semantic pattern in which the occurring elements of the fragment play a role, the semantlc class PATIENT can be speclfled for the deleted subject. Batlent is one of the distinguished words in the domain of narrative medical records which are often not explicltiy mentloned in the text, al though they play a role in the semantic patterns.

The S-V-O relations, of whlch the fragment types are incomplete realizations, form the basis of a procedure which specifles the semantle classes of deleted el ements In fragments. Under the best conditions, the set of semantic classes for the deleted form contalns only one element. It is also possible, however, for the set to contain more than one semantic class. For example, the type la fragment Baln also noted in hands and knees, when regularlzed to normal active $S-V-0$ word order as neted pain In hands and knees, has a deleted subject. The set of posslble medical classes for the deleted subject consIsts of ¿PATIENT, FAMILY, OOCTOR $\}$, since a fragment ith a verb of the OBSERVE class, such as note, and an object of the SIGN/SYMPTOM class, such as paln, can enter irte

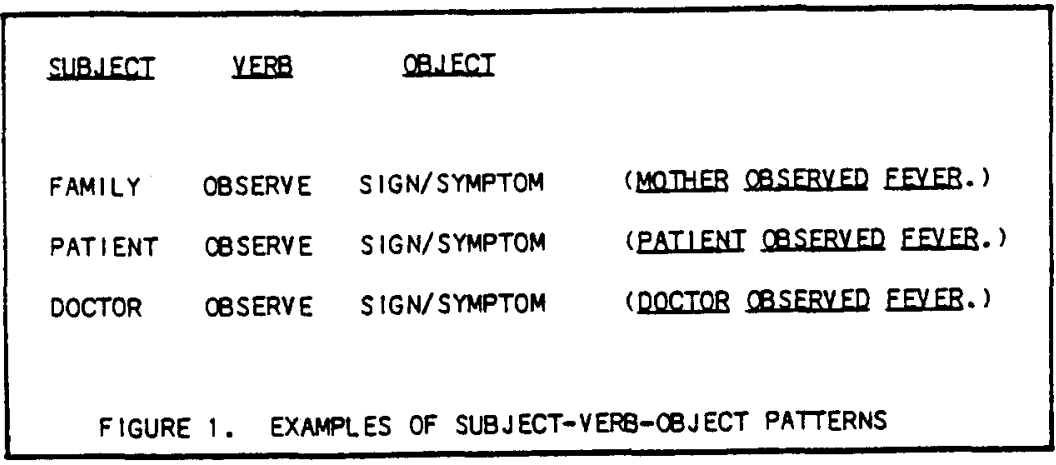


any of the S-Y-0 patterns In Figure 1. The cholce of one subclass for the del eted el ement from among elements of the set of possible subclasses is dependent on several factors. First, propertles of paragraph structure of the text place restrictions on the selection of sementic class for a deleted el ement. The fragment noted dea in hands and kneas would sol ect a DOCTOR subject if written in the IMPRESSION or EXNM paragraph of the text, but, In the HISTORY paragraph, a PATIENT or FAMILY subject could not be excluded. A second factor is the presence of an antecedent havling one of the semantic classes specifled for the deleted el ement. If a possible antecedent hoving the same semantlc class can be found, subject to restrictions on change of topic and discourse structure, then the deleted el ement can be fllled In by its antecedent, restrlcting the semantlc class of the deleted element to that of the antecedent. However, an antecedent search may not always be successful, since the antecedent may not have been expl leltly mentloned in the text. The antecedent may be one of a class of distingulshed words in the sublanguage, such as patient and doctor, whlch may not be prevlously mentloned in the body of the text.

Thus, semantic potterns derived from distributional analysis permit the specitication of - sot of semantlc classes for deloted el ements in texts characterlzed by a large proportion of sentence fragments. $\mathrm{m} / \mathrm{s}$ specification can facllitate the reconstruction of deleted el ements by limiting cholce anong possible antecedents.

\section{iv. CONCLUSION}

In this paper, seven deletion patterns found in technical compact text have been identifled. The number of fragment types is relatively IImIted. Five of the seven occur in the full grammar of English as subparts of fuller structures. These syntactic fragment types can be vlewed as incomplete realizations of syntactic SUBJECT-VERB-0BJECT structures; the senantlc patterns in sentence fragments are found to be incomplete raallzations of the sementlc SUBJECT-VERB-CBJECT patterns found in full sentences. Semantic classes can be speclfied for deleted el ements in sentence fragments based on these semantic patterns.

\section{ACKNOWLEDGMENTS}

\footnotetext{
This research was supported in pert by National Sclence Foundation grant number IST79-20788 from the olvision of information Sclence and Technology, and in part by Natlonal Llbrary of Medlcine grant number 1-RO1-LMO3933 awarded by the National Institute of Health, Department of Health and Human Services.
}

\section{REFERENCES}

Anderson, B., Bross, I.D.J. and N. Sager (1975). Granmotical Compression in Notes and Records. Amerlean Journal of Computational hinouistles 2:4.

Grishman, R., Hirschmen, L., and C. Frledman (1982). Natural Language Interfaces Using Limited Semantic information. Brocaedinos of 9th International Conference on computational Inaulatias (COLING 82), Prague, Gechos lovakle.

Hendr Ix, G. (1977). Humen Engineering for Appl led Natural Language Processing. Eroceedinas of th LiCal, Cambrldge, Mass.

Hendr Ix, G., Sacerdoti, E., Sagalowlcz, D., and J. Slocum (1978). Developing a Natural Language intertace to Complex Data, ACY IDOS 3:2.

Hirschmen, L. and N. Sager (1982). Automatle Information Formetting of a Medical Sublanguage. Sublanouage: Studies of Lanouage In Bextriated Semantic Domalas (R. Kittredge and J. Lehroerger, ods.). Walter de Gruyter, Berlin,

Kmasny, S.C. and N.K. Sondhelmer (1981). Relexation Techniques for Parsing 111 -formed Input. Anerican journal af computational Lnoulstias $7: 2$.

Marsh. E. and N. Soger (1982). Analys/s and Processing of Compact Text. Eroceadings of the 9th Lnternational Conference on Computational Lingulstias (COL ING 82), Prague, Gechos lovakla.

Sagor, N. (1978). Notural Language informatlon Formatting: The Automatic Conversion of Texts to a Structured Data Base. In Advances in Computers 17 (M.C. Yovits, od.), Academlc Press, New York.

Waltz, D. (1978). An English Language Question Answerling System for a Large Relational Data Boso, CACY 21:7. 